\title{
Dinî Hayatın Ritmi: Ritüel ve Müzik
}

\author{
İLKAY ŞAHIN \\ DR., ERCIYES Ü. İLAHIYAT FAKÜLTESI \\ e-posta: isahin@erciyes.edu.tr
}

\begin{abstract}
Rhythm of Religious Life: Ritual and Music. Ritual and music with repeated, patterned, sequential structural properties and symbolic semantic contents are socio-cultural practices which provide social dimension to religion and make religion subject of collective sharing. Thus, rituals associated with the social dimensions of religiosity rather than the practical aspects have allowed religion to express itself and brought about social solidarity and cohesion. Music has represented a ritual character on the basis of properties such as repeated, patterned, sequential and emotional density, and these properties have got a sacredness and significance in the ritual context. Music as important components of ritual, has allowed characters arising from structural and semantic features of rituals to continue by strengthening. The subject of this research is to analyse the relationship of music and ritual between social dimension of religiosity in the theoretical framework. Following an assessment about importance of religiosity in the theoretical framework. Following an assessment about importance of music in socio-cultural life, significance of music achieving in the context of ritual is evaluated on the heading of ritual music; the role of ritual music in the individual and social dimension of religiosity is discussed.
\end{abstract}

key words

Ritual, Music, Ritual Music, Religiosity, Religious Life.

\section{Giriş}

Toplumlar, kutsalla kurdukları her türlü iletişim ve tecrübeyi bireysel boyutuna rağmen sosyokültürel yaşamın oluşum ve devamlılığı için atıf çerçeveleri inşa etmek üzere kolektif bir paylaşımın konusu haline getirme eğiliminde olmuşlardır. Kutsalı toplumsallaştırma ve kolektif bir paylaşımın konusu haline getirme girişimi ise toplumların inanç ve pratiklerinin benzer ortak temeller üzerine inşa edilmesi sonucunu doğurmuştur. Kutsalın kolektif bir paylaşımın konusu olacak biçimde toplumsallaşmasını sağlayan bu ortak temellerden insanlığın en aşina olduğu ise ritüellerdir.

Ritüeller, kutsalla ilişkinin teorik boyutunun yani inancın sosyokültürel yaşam içinde sindirilmesini ve kolektif bir paylaşımın konusu haline gelmesini sağlamaktadır. Ancak şunu da belirtmek gerekir ki kutsalla kurulan iliş- 
kinin teorik boyutu kurumsal dinler söz konusu olduğunda genel olarak "inanç", pratik boyutu ise "ibadet" olarak tanımlanırken, kurumsallaşmamiş dinler söz konusu olduğunda teorik boyut "mit" pratik boyut ise "ritüel" olarak kavramlaştırılmaktadır. Nitekim bu durumu doğrular biçimde 19. yüzyıldan itibaren Batı dünyasındaki akademik çalışmalarda yerini almaya başlayan ritüel kavramı uzunca bir süre "ibadet" kavramını işaret edecek şekilde kullanılmıştır (Platvoet, 2006: 162). Böylesi bir kavramlaştırmanın mit ve ritüeli gelişmemiş toplumlarla ilişkilendirerek ötekileştirmesi bir yana ritüellerin kurumsal dinler bağlamında dinî pratikler ya da ibadetlerin bir biçimi olarak görülmesi sonucunu beraberinde getirmiştir. Oysa ritüeller, dinin de dahil olduğu sosyokültürel yaşamın kutsallık kaynaklarını eylem içinde somutlaştırarak toplumsallaştıran, salt ibadet ya da dinî pratikle özdeşleştirilemeyecek kadar geniş bir kavramsal içeriğe sahiptir. Ritüelin kolektif bir paylaşımı üreten ve toplumsallaştıran bu karakteri kavramsal içeriğine tipik bir biçimde yansımaktadır

Tüm kültürlerin temel unsurlarından olmasına rağmen Türkçenin de dâhil olduğu pek çok dilde Batılı terim "ritüel"e benzer çeşitli kavramlar kullanılmakla birlikte doğrudan doğruya ritüeli karşılayan genel bir kavramın bulunmadığ görülmektedir. Sosyokültürel yaşam içinde ritüellere dair bir üst dilin oluşmayışı ritüellerin toplumsal yaşama içkin doğasının dile yansıyan boyutunu gözler önüne sermektedir (Stausberg, 2006:59, 94, 97). Toplumsal yaşama içkin karakteri ile ritüeller sosyokültürel hayatın kutsallarını toplumsallaştırmakta; dinle çeşitli biçimlerde ilişkili olan geleneğin kutsallıklarına dair referansları bünyesinde barındırdığı gibi dinî inançları eyleme dönüştürerek kolektif bir paylaşımın konusu haline getirmekte, dindarlığın toplumsal boyutunu inşa etmektedir. Ritüellerin sosyokültürel yaşamın temel atıf çerçevelerini oluşturan kutsallık kaynaklarını bünyesinde barındırabilen ve kutsalları toplumsallaştırabilen bu özelliği dinî inancın sosyokültürel hayat bağlamında kolektif bir paylaşımın konusu haline gelmesini sağlamaktadır. Bu doğrultuda olmak üzere her biri ayrı kuramsal bir geleneği takip etmişse de Durkheim'den Turner ve Goffman'a kadar pek çok araştırmacı kolektif paylaşımı yaratan özelliklerini vurgulayarak ritüelleri sosyokültürel yaşamın ve dinî hayatın temel biçimlerinden biri olarak değerlendirmişlerdir.

Durkheim, din olgusunu kavramlaştırmak amacıyla belirlediği temel bileşenleri iptidai toplumlar merkezinde analiz ederken söz konusu unsurların aslında dinî hayatın günümüze değin gelen temel biçimleri olarak görülebileceğini ifade etmektedir. Bir ölçüde de olsa kutsallığı barındırmayan hiçbir ritin olamayacağını belirten Durkheim'e göre ritler bireyi mensubu 
olduğu topluma bağlayan bağları güçlendirmekte-, toplumu yeniden üretmekte ve yaratmaktadır (Durkheim, 1947:225-226). Toplumsal yaşamı yaratan karakteri ise ritüelleri dinî yaşamın temel biçimlerinden biri haline getirmektedir. Durkheim'in iptidai dinlere ilişkin görüşlerinin analitik terimlerini kendi modeli içinde kentsel seküler yaşamı anlamak üzere kullanan Goffman, insanlığın sosyal ilişkilerinin değişmeyen temel karakterine dikkat çekmektedir. Goffman'a göre seküler olarak tanımlanan günümüz dünyası aslında kutsallıktan arınmış seküler bir dünya değil, kutsallığın yeniden, kişiler arası ilişkilerde üretildiği bir dünyadır. Kişilerarası ilişkilerin ritüel formları ise kutsallığın üretildiği yerdir (Goffman, 2006: 81, 95). Sosyokültürel yaşamın organizasyon biçimindeki tüm değişikliklere rağmen ritüellerin dönüşüme uğrayarak da olsa sosyal ve dinî hayatın temel biçimlerinden biri olmaya devam ettiğini vurgulayan Turner, örnek olarak hac ritüelini göstermektedir. Buna göre kurumsal dinlerdeki hac, yazılı kültüre dayanmayan toplumlarda geçiş ritleri ile bir talihsizlik ya da bir hastalıktan kurtulmak üzere düzenlenilen ritlerin fonksiyonel benzeridir (Turner, 1974:65).

Kutsalı barındıran, üreten ve kolektif bir paylaşımın konusu haline getiren niteliği ile ritüelleri dinî hayatın ve toplumsal yaşamın temel biçimlerinden biri olarak kavramlaştıran bu değerlendirmelerden de anlaşılacağı üzere ritüeller inanca toplumsal bir boyut katmakta, inancın ifade edilmesini sağlamakta, böylece birey ve toplum arasında bir köprü kurmaktadır. Dinler, kutsalla iletişimi tanrı-insan ilişkisi temelinde bireysel bir zemin üzerine kursalar da söz konusu inançlar sosyokültürel yaşamın temel biçimlerinden ritüeller içinde toplumsallaştırılmakta ve kolektif paylaşımın konusu haline gelmektedir. Bu yönüyle ritüeller dinlerin kendilerini ifade etme, toplumsal yaşamın bir parçası haline gelmelerinin önemli bir kanalı olma niteliğini taşımakta, dindarlığın pratik boyutunun ötesinde toplumsal ve kültürel boyutu bağlamında bir anlam ve önem kazanmaktadır. Din ve ritüeli Durkheim geleneğinin aksine kültür merkezli bir yaklaşımla anlamaya çalışan ve Turner gibi dini kültürün, ritüelleri de dinin anahtarı olarak gören Geertz (Segal, 1983:327), ritüellerin sosyokültürel yaşamı bir model olarak bünyesinde barındıran niteliğine işaret etmektedir. Böylece ritüellerin dinin kendisini ifade etmesini ve toplumsal bir boyut kazanmasını sağlayan karakterinin yanında anlamlandıran ve anlamlanan kültürel boyunu da gözler önüne sermektedir. Geertz'e göre belirli semboller kompleksi tarafından yaratılan dinî ritüeller aynı anda hem mevcut gerçekliğin bir modeli (a model of) hem de olması gereken gerçeklik için bir model (a model for) olma özelliğine sahip bir değerler sistemini oluşturmaktadır. Söz konusu sembolik sistem 
ise hem mevcut sosyal durumu temsil eden hem de yeniden şekillendiren bir etkiyi yaratmaktadır. Geertz'in ifadesiyle;

Bir ritüelde yaşanan bir şey olarak dünya ile tasavvur edilen bir şey olarak dünya, tek bir sembolik formlar dizisinin failliği altında kaynaşmış olarak aynı dünya olmaya yönelir...(Geertz, 2004: 28) ... Tek bir semboller seti aracılığılyla bir dizi ruh hali ve motivasyonun -etosun- teşvik edilmesi ve bir kozmik dünyanın -bir dünya görüşünün- tanımlanmasıyla performans dinî inancın bir şey için model ile bir şeyin modeli boyutlarını birbirinin yerine geçişlerden ibaret kılar (Geertz, 2004: 34).

Dinlerin kendilerini ifade etmek ve bireysel bağlamlarının ötesinde toplumsal yaşamın bir parçası haline gelmek, toplumsal bir boyut kazanmak üzere başvurdukları bir diğer önemli kanal ise sanattır. Müzik, kolay icra edilebilirliği ve ulaşılabilirliği, yaygın ve kolay etkileme gücü ile dinlerin kendilerini ifade etmek ve toplumsal bir karakter kazanmak üzere müracaat ettikleri sanat türlerinin başında gelmektedir. Sosyokültürel yaşamın önemli bileşeni olan müzik, özellikle ritüeller bağlamında oynadığı, dramatizasyon, duygusal yoğunlaşmayı sağlama gibi nitelikleri ile dinî hayatın önemli bir parçasıdır. Kimi zaman eğlence ve dünya zevkleri ile ilişkilendirilen boyutu nedeniyle yadsınmasına ve şüpheyle karşılanmasına (Stokes, 1992:214), kimi zaman da modern yaşamın iş ve boş zaman ayrımına dayalı olarak bir boş zaman etkinliği olarak değerlendirilip sosyokültürel yaşam ve dinî hayatla doğrudan ilişkilendirilmemesine rağmen tüm dinler belirli formlarda da olsa mutlaka müziği bünyesinde barındırmakta, hatta çoğu din için müzik merkezî bir öneme haiz bulunmaktadır (Alcorta, Sosis, 2005:345). Özellikle dinî pratikler bağlamında önemli rolleri oynamakta, uyarıcı ve etkileyici, duygusal olarak birleştiren ve bağlayan, derinleşmeye imkân tanıyan karakteri ile Hristiyanlık, Müslümanlık ve Hinduizm gibi dinlerde ritüeller bağlamında etkin bir biçimde kendini hissettirmektedir. Bu yönüyle her ne kadar yarattığı duygusal dönüşümlerle bireysel düzeyde önemli etkileri beraberinde getirse de müzik, aslında ortaya çıktığı kültürel bağlamla doğrudan ilişkilidir (Clark, 2006:475). Reklâmlardan filmlere spordan ibadete kadar uzanan sosyokültürel eylemlerin geniş bir yelpazesi içinde insan yaşamına doğrudan ya da dolaylı etkilerde bulunabilen karakteri ile müzik, sosyokültürel yaşamın ve dinî hayatın ayrılmaz bir bileşeni olup sosyokültürel eylemler çerçevesinde anlamlı hale gelmektedir (Hays, Minichiello, 2005:84). Sosyokültürel pratikler, özellikle de dinî ritüeller çerçevesinde bir anlam ve kutsiyet kazanan müzik ise genelde sosyokültürel yaşam özelde dinî hayat bağlamında önemli etkileri meydana getirmektedir. 
Sosyokültürel eylemler çerçevesinde anlamlı hale gelen karakterine karşın birey tarafından yaratılma niteliği ve birey bağlamında yarattığı duygusal dönüşümler genelde müziğin sosyokültürel yaşamla etkileşimine özelde ise dinin toplumsal boyutu ile ilişkililiğine sınırlı düzeyde ilgi duyulması sonucunu beraberinde getirmiştir. Ancak şunu da belirtmek gerekir ki sosyal bilimler alanında etkileşimci yaklaşımlardaki artış müzik ve toplum ilişkisine duyulan ilgiyi artırmış, müziğin sosyal boyutu değişen yoğunluk ve biçimlerde vurgulanmaya başlanmıştır. Bu çerçevede olmak üzere bir yandan son yüzyıl boyunca kültürel yaşamın karmaşık doğası ile müzik ilişkisi ele alınırken, diğer yandan da daha sosyolojik bir bakışla müzik ve toplum ilişkisi değerlendirilmiştir. Müziğin sosyokültürel yaşamla etkileşimi farklı disiplinler tarafından değişen yoğunluklarda vurgulanmış, sosyal süreçlerle ilişkisi antropoloji ve müzikoloji için önem arz etmese de müzik sosyolojisi için merkezî bir öneme sahip olmuştur. (Kaemmer, 1980:61-62). Zira toplum, ekonomi, teknoloji, şehirlileşme, etnik köken, sosyal organizasyon ve yapının müzisyenleri ve ürettikleri eserleri ne yönde etkilediği müzik sosyolojisinin temel konularını oluşturmaktadır (Turley, 2001:648). Mozart'ın müzikal kabiliyeti ve eserlerinin sosyal sinıf sistemi ve sosyokültürel bağlamdan etkilenen karakterini sosyolojik bir yaklaşımla analiz eden Elias'ın çalışması müziğin sosyal süreçlerle ilişkililiğini göstermeyi hedefleyen müzik sosyolojisi alanında yapılmış çalışmalara tipik bir örnektir (Elias, 2000). Din ve müzik ilişkisi ise farklı yönleri ile ele alınmış, özellikle müziğin ritüel bağlamı çeşitli dinî sistemler örneğinde değerlendirmeye tabi tutulmuş, bu bağlamda geniş bir literatür meydana gelmiştir.

Müziğin sosyokültürel yaşamla, özellikle de dinî hayatla ilişkisine dair bir değerlendirme yapmayı hedefleyen bu çalışma, müzik-din ilişkisini müziğin ritüeller bağlamında anlam ve önem kazanan niteliğini vurgulayacak biçimde ritüeller ekseninde, sözü geçen literatüre dayalı olarak teorik bir biçimde ele almayı kendisine konu edinmiştir. Bu çerçevede olmak üzere müziğin sosyokültürel yaşamla ilişkisi değerlendirildikten sonra dindarlığ 1 çeşitli biçimlerde etkileyen, ritüeller bağlamında anlam ve önem kazanan karakteri ele alınacaktır.

\section{Sosyokültürel Yaşamın Ritmi: Müzik}

Kimi zaman sadece sözlerin melodik ve ritmik bir biçimde sıralandığı kimi zaman da sözlere çeşitli aletlerin eşlik ettiği müzik, toplumların sosyokültürel miraslarının sembolik göstergesi, ifade etmenin özel ve güçlü bir kanalı olan bir sanat türüdür. Diğer sanat biçimlerinden farklı olarak birey ve sosyokültürel yaşam üzerinde yaygın ve güçlü etkileri meydana getiren müzik, 
bir hedefi ve amacı olmayan, melodisi, ritmi ve tonlaması tümüyle kendine özgü, belirli kurallara göre meydana getirilen estetik ve manevi bir gerçekliktir. İnsan ruhuna dokunan manevi ve sanatsal doğası sadece kulakla duyma ya da kelimeler arasında sunulmaya bağlı olarak değil, anlama ve yorumlamaya dayalı olarak açığa çıkmaktadır (Andrews, 1916:331).

Bireylerin ve toplumların değer dünyasına dokunan naif yönü, anlaşılmayı ve yorumlanmayı gerektiren kendine özgü sembolik ve estetik doğası "müzik nedir?" ve "sosyokültürel yaşamın neresinde durmaktadır?" sorularına farklı cevaplar verilmesine neden olmuştur. Din sosyolojinin kurucuları arasıda sayılan İbn Haldun bu soruya bundan yüzlerce yıl önce toplumların gelişmişlik düzeyi ile müzik arasında kurduğu ilişki bağlamında cevap vermiştir. Müzik türleri ve aletlerine, müzisyenlere dair ayrıntılı bir analizde bulunan İbn Haldun müziğin toplumların kültürel gelişmişlikleri ile ilişkiliğini vurgulamış, sosyal yaşamdaki çözülmenin de ilk ifadesini sosyokültürel yaşamın bir göstergesi olarak müzikte bulduğuna işaret etmiştir (İbn Haldun, 1991:432-437). Böylece İbn Haldun müziği sosyokültürel yaşam bağlamında ortaya çıkan, aynı zamanda da sosyokültürel yaşamı temsil eden bir sanat türü olarak değerlendirmiş, bu anlamda müzik sosyolojisine kayda değer bir katkı sağlamıştır. İbn Haldun'un doğrudan sosyokültürel yaşamla ilişkilendirdiği müzik, bireysel ve toplumsal yanı dikkate alınarak çeşitli biçimlerde kavramlaştırılmışır.

Bireylerin içsel dünyalarından kaynaklanan ve yine bu dünyaya dokunan tınılarıyla bireysel bir boyutu bulunan, ancak sosyokültürel yaşamın değer ve dünya görüşünün gölgesinde vücut bulan doğası ile sosyal ve bireysel olanın arasında estetik bir köprü olarak müzik, gramer yapı üzerine inşa edilen ancak bu yapının içinde anlamsal kodları saklayan bir dil, temel karakteri itibariyle bir ritüel ya da sosyal yapıya benzer müzikal bir yapı olarak değerlendirilmiştir. Öyle anlaşllıyor ki bireysel ve sosyokültürel bă̆lamına ilave olarak manevi ve estetik boyutu ile anlamlandırılmaya muhtaç çoklu sembolik etkenlerin bir bileşimi olan müzik, sosyokültürel yaşamın dil, ritüel, sosyal yapı gibi ortak bazı özelliklerde buluştuğu unsurlarına nispetle kavramlaştırılmaya çalışılmıştır.

Müzik, yapısal ve anlamsal karakteri itibariyle kendisine benzeyen sosyokültürel hayatın önemli bir bileşeni dil ile kurulan çeşitli analojiler vasıtasıyla linguistik bir eğilimle öncelikle bir dil olarak kavramlaştırılmıştır. Müziğin bir dil olarak tanımlanmasının yanında müzikteki dil, dildeki müzik, müziğe dair dil de müziği anlama girişiminin önemli bir parçasını oluşturmuştur. Müzikal yapı ile gramer kategorileri arasında kurulan analojiler ya da sentaks, morfoloji ve fonoloji vurgusu müziğin bir dil olarak görülmesini 
beraberinde getirmiştir. Bir dil olarak müzik, dil ve müziğin bilişsel boyutunu öne çıkarmıştır. Buna karşın daha ampirik ve işlevselci bir yaklaşımla sözlü sanat, şarkı metni ve müziğin icrasında dil ve müziğin birbirine geçmiş özelliğine fenomenolojik bir eğilimle yapılan vurgu müzikteki dili anlamaya yöneliktir. Müzik ve dil arasında kurulan bir diğer benzeşim ise vezne dayalı olarak dilin müzikal niteliğinin yani dildeki müziği, müziğin estetik ve teknik niteliklerine yapılan vurgu ise müziğe dair dili anlamaya yöneliktir. Bir dil olarak müzik kavramının bilişsel boyutuna karşın ampirik ve işlevselci bir algıyı gözler önüne seren müzikteki dil, dildeki müzik, müziğe dair dil yaklaşımları müzikal söylemlerin iletişim nitelikleri ve sosyal fonksiyonları arasındaki ortaklık ve zıtlıklara işaret etmektedir. Böylesi bir eğilim ise müziğin karakteri, biçimi ve icra edilişi ile cinsiyet, sosyal sınıf ve kurumlar gibi toplumsal kategoriler arasındaki ilişki biçimini göstermeyi hedefleyen sosyal vurgusu yüksek bir bağlamı oluşturmuştur (Feld, Fox, 1994:26-27).

Bilişsel boyutu öne çıkartılacak biçimde bir dil olarak değerlendirilmesine karşın kültürün önemli bir bileşeni olarak müziğin, bilişsel ve sosyal süreçlerin ortak bir ürünü olduğu gerçeği sosyal ve kültürel süreçlerin de dikkate alınmasını beraberinde getirmiştir. Özellikle etkileşimci yaklaşımların sosyal bilimler alanında giderek etkisini artırmasıyla birlikte müzik ve toplum ilişkisine duyulan ilgi de aşikâr hale gelmiş, müziğin sosyal boyutu değişen yoğunluk ve biçimlerde vurgulanmaya başlanmıştır (Kaemmer, 1980: 61-62). Müziğin toplumsal boyutuna dikkat çeken yaklaşımların da vurguladığı üzere müzik, sosyal ve kültürel gerçeklik içinde vücut bulmakta, toplumsal ilişkiler bağlamında yaratılmaktadır. İnsanların fiziksel, psikolojik özellikleri müziğin yaratılması ve tecrübe edilmesinde etkili ve belirleyici olsa da müzik yapmak ya da dinlemek fiziksel dünya ve yaşanılan sosyal çevreyle kurulan farklı ilişki biçimlerinden etkilenmektedir. Bu çerçevede olmak üzere müziğin yapısı ile sosyal ve kültürel pratiklerin formel yapısı arasında bir paralellik kurulabileceği gibi sosyokültürel yaşamdan etkilenen ve sosyokültürel yaşamı etkileyen karakterine de dikkat çekilebilmektedir (Begbie, 2000:13-15).

Sosyal yapı ile müzikal yapı arasında kurulan ilişki her iki yapının karşılıklı olarak birbirini etkileme özelliğini gözler önüne serebileceği gibi uyumlu birlikteliklerine de işaret edebilmektedir. Nitekim müziğin toplumsal karakterini sosyal yapı ile müzikal yapı arasında kurduğu ilişki bağlamında ele alan Feld, müzikal inanç, yapı ve eylemlerin toplumların sosyokültürel yaşamı ve yapısal özellikleri ile uyumluluk arz ettiğini vurgulamaktadır. Ona göre sosyal yapı ile müzikal yapı arasında karşılıklı olarak birbirini etkileyen bir ilişkiden daha ziyade bir uyumluluk söz konusudur. Sosyal yapı ile müzi- 
kal yapının uyumluluğu ise müzikal yapının insanların kimlikleri ve sosyal bağlamlarına dair mesajları taşımasında belirgin bir biçimde görülmektedir. Feld'e göre kadın ve erkeğin sosyal konum ve statüleri ile müzikal yapı arasındaki uyumluluk bu durum için tipik bir örnek olup sosyal yapının kadın-erkek eşitsizliğine dayalı özelliği müzikal organizasyon içinde temsil edilmektedir. Müzikal yapının kimlik ve sosyal sınırlara dair bu tür mesajları ise bir anlamlandırma etkinliğini gerektirmektedir (Feld, 1984b:400, 403, 405-406).

Tıpkı Feld gibi Lengel de cinsiyet kategorisinden hareketle müziğin sosyokültürel bir bağlam çerçevesinde ortaya çıkışını, anlamlı hale gelişini, aynı zamanda bir anlamlandırma etkinliğini gerektirişini, sosyal yapı ile ilişkililiğini vurgulamaktadır. Lengel'e göre müzik kadınlara kendileri hakkındaki hikâyelerini sunmalarına imkân tanıyan yine kendi sosyal ve kültürel koşullarından beslenen sözlü kültürün önemli bir bileşenidir. Müzik, kadınlara kendilerini ifade etmeleri, kendi güçlerini ve biyolojik kimliklerini kutlamaları ve sosyal yapının erkek baskın doğasını eleştirmeleri için estetik bir kanal yaratmaktadır. Ancak sadece sosyal yapının sınırlamalarından kurtulmalarının önünü açmamakta aynı zamanda da kendilerine güvenmeleri ve kendilerini güvende hissetmeleri için de bir ortam yaratmaktadır (Lengel, 2004: 222, 224-226).

Sosyal bir bağlam çerçevesinde inşa edilen müzik, yine bu sosyal bağlama dayalı bir yorumlama ile anlamlı hale gelmekte, sosyal yapıya ilişkin bağlamı bir anlamlandırma ve yorumlama etkinliğine dayalı olarak ortaya çıkmaktadır. Söz konusu anlamlandırma süreci sosyal olarak inşa edilen müziğin toplumsal yaşamı etkileme eğilimini de beraberinde getirmektedir. Müziğin sosyal yapı içinde şekillenen, aynı zamanda da sosyal yapıyı anlamlandıran bu toplumsal bağlamı inanç ya da ideolojiyi ifade etmek ve buna dayalı bir kimliği kurmak suretiyle sağladığı sosyal bütünleşmeyi sürdürme özelliğinde somutlaşmaktadır. Sosyal yapının temel karakteri ile uyumlu bir ideolojiyi taşıyan ve bu ideolojiye uygun bir kimliği oluşturarak toplumsal uyumun devamlılığını sağlayan etkisi esas alındığında ise müzik, metaforik bir süreç olarak karşımıza çıkmaktadır (Feld, 1984a:7, 12-13). Zira sembollerin oluşması ve yorumlanması, dolayısıyla da kültürün ayakta kalması bu metafora bağlıdır. Bu nedenle sosyal yapı ile ses yapısı arasında bir korelasyondan daha ziyade toplumların metaforlarına bağlı, metafor merkezli bir uyum ve tutarlılı bulunmakta, müzik süregelen sosyal yapının ve kültürün uyumlu bir parçası olarak toplumsal yaşamda yerini almaktadır. Ancak şunu da belirtmek gerekir ki sosyal olarak anlamlı ve önemli her hususun müzikal bağlamda temsil edilmesi gerekmezken müzik sistemi içinde işaret edilenler toplumsal bir gerçekliği göstermektedir (Feld, 1984b:405-406). 
Müziğin toplum ve kültürle ilişkilendirilişi çerçevesinde sosyal yapı ve müzikal yapı arasında kurulan bu türden etkileşimin ötesinde daha ampirik ve fonksiyonel bir bakış açısıyla dinleyici ve icra edenlerin belirli bir sosyokültürel bağlamın ürünü olduğu göz önünde bulundurularak toplumsal yaşamın müzik türlerine etkisi ile müziğin toplumsal yaşamdaki rolünden de bahsedilmektedir. Söz konusu sosyal etkiler ekonomik buhran, kitlı ya da Cerulo'nun incelediği şekliyle savaş gibi yıkıcı etkenler olduğunda sosyal durumların müziğe olan etkisi daha belirgin bir biçimde açığa çıkmaktadır (Cerulo, 1984:886). Benzer bir biçimde statü farklılıkları ve düşük sosyoekonomik konum gibi sosyal yapının belirleyici özellikleri ile müzik arasındaki ilişkiyi elit müziği ile popüler müzik örneğinde ele alan Blau, müzik türleri ile sosyoekonomik yapı arasında doğrudan bir ilişki olduğu sonucuna ulaşmış, toplumun yapısal özelliklerinin müziğe etki eden yönüne işaret etmiştir.

Buna göre düşük sosyoekonomik statüye sahip insanlar popüler müziğe daha yoğun bir biçimde yönelmekte, ekonomik eşitsizlik ve dezavantajlar tercih edilen müzik türünü etkilemektedir. Ayrıca daha düşük sosyoekonomik statüyü temsil eden popüler müzik ile şiddete dayalı suçlar ve intihar gibi anomik durumlar arasında doğrudan bir ilişki varken böylesi bir ilişkiye elit kurumsal müziğinde rastlanmamaktadır. Bu durum müziğin ekonomik yetersizlik, suç, boşanma, intihar gibi durumlar için bir kaçış vanası oluşturma niteliğini de gözler önüne sermektedir (Blau, 1988:890-891, 895-896). Benzer bir biçimde intihar ve müzik ilişkisini inceleyen Stack ve Gundlach ise Amerikan folk müziğinde geçen bazı temaların bu müziğin yaygın olduğu düşük sosyal statülü etnik gruplarda intihar eğilimini artıran boyutuna işaret etmiştir (Stack; Gundlach, 1992:211, 215). Müziğin sosyal yaşama olan bu türden olumsuz etkilerinin yanında sosyal uyum ve bütünleşmeyle ilişkili etki ve rolleri de bulunmaktadır.

Yarattığ1 toplumsal etkileri nedeniyle spordan ibadete kadar uzanan sosyal ve kültürel eylemlerin geniş bir yelpazesi düzeyinde toplumsal yaşamın merkezinde uzanan müzik (Hays, Minichiello, 2005:84) sosyal kimliğin bir işareti, sosyalizasyonun ve ideolojik bir model oluşturmanın önemli bir arac1, cinsiyet ve sınıf ilişkilerinin de dahil olduğu mevcut sosyal yapının eleştirisi için bir mekanizma, metafizik tecrübenin ifade edilmesini sağlayan güçlü bir kanaldır (Feld, Fox, 1994:35). Kimlik ve aidiyetle ilgili güçlü bir referans kaynağı, sosyokültürel yaşamın geneliyle, gelenek ve değişimle uyumlu bir sanat olan müzik sosyal sorunlar ile çeşitli duygusal eğilimlerin dışavurumu içinde de güçlü bir araçtır (Tracey, 1954:235).

Duygusal ifadenin ötesinde duyguları zenginleştirmekte ve yeniden şekillendirmekte, böylece insanların müzikal bir eylem içinde sosyalleşmeleri 
ve öğrenmeleri sağlanmaktadır (Begbie, 2000:18). Bu doğrultuda olmak üzere sosyokültürel olarak onaylanmış davranış biçimleri müzik içinde çeşitli biçimlerde sunularak ahlaki bir model oluşturulmaktadır. Sosyal ilişkilerde kırılmalara yol açmaksızın bireylerin kendilerini ifade etmesine imkân tanıyan boyutu da sosyal hayatın devamlılığı anlamında önem arz etmektedir (Tracey, 1954:237). Sosyal norm ve değerlerin öğrenildiği tüm bu sosyalleşme sürecinin sonucu ise toplumsal uyum ve bütünleşmedir. Toplumsal yaşamın sınır ve ilkeleri, kural ve davranış biçimleri ninniden ulusal marş ve ilahilere kadar uzanan çeşitli müzik biçimleri bağlamında güçlendirilmek suretiyle bir yandan sosyal uyumun devamlllığı (Blau, 1988:884), diğer yandan da grup ve toplum dayanışmasının artması sağlanmaktadır (Alcorta, Sosis, 2005:348).

Sosyokültürel yaşam bağlamında oynadığı tüm bu etki ve fonksiyonları ise müziğin tek başına anlamsal kodları taşıyan bir iletişim aracı olmaktan daha ziyade sosyokültürel bağlam çerçevesinde anlamlı hale geldiğini akla getirmektedir (Begbie, 2000:4, 9). Bu fikri destekler bir biçimde Regelski müziğin bizatihi kendi başına bir anlam ifade etmediğini, boş zaman etkinliklerinden dindarlığa kadar uzanan sosyal pratiklerin geniş bir alanı içinde kullanılmak üzere varolduğunu, ancak sosyokültürel bağlam çerçevesinde bir anlam ifade edebildiğini belirtmektedir. Müziğin anlamı, ses düzeni ya da icra etme eylemi içinde yaratılmamakta, tam aksine eşlik ettiği sosyal pratikler merkezinde açığa çıkmakta ve oluşmaktadır. Dolayısıyla müziğin anlam ve önemi sosyal bağlamı, dinleyicilerin konum ve koşulları çerçevesinde şekillenmekte, sosyal koşullar müziğin kullanımını ve anlamını belirlemektedir (Regelski, 2006:291, 294). Müziğin sosyokültürel bir bağlama göre anlamlı hale gelişinin en tipik örneğini ise ritüeller oluşturmaktadır.

\section{Ritüel Müzik}

Seküler ya da dinî ama mutlaka atfedilmiş ya da bizatihi kutsallıkla katışık bir karaktere sahip olan ritüellerin duygusal yoğunlaşmayı sağlama özelliği toplumsal bir güdülenmenin temelini oluşturmakta, böylesi bir ortamda ise nesneler, yerler, inançlar anlamla yüklenmektedir. Ritüeller ekseninde kolektif duygusal yoğunlaşmanın önemli bir ayağını oluşturan müzik ise ritmin ardındaki söylemleri ilişkili oldukları bağlama taşıyarak bir yandan anlamlandırırken diğer yandan da anlamlı hale gelmektedir (Alcorta, Sosis, 2005:338). Müziğin özellikle ritüeller bağlamında açı̆̆a çıkan anlamlandıran ve anlamlı hale gelen bu gücü ise ritüellerle paylaştı̆̆ı ortak bazı özelliklerinden yani müziğin ritüel karakteri ve gücünden ileri gelmektedir. 
Müzik tıpkı ritüel gibi biçimsel, ardışık, tekrarlanabilir niceliği ve yararcı hedefler üzerine inşa edilmeyen karakteri ile sosyokültürel bir eylemdir. Her ikisi de zamanlı ve geçici bir kaynaktan beslense de önceden belirlenmiş kurallara bağlı oluşları tekrarlanabilirliklerini beraberinde getirmektedir Aynı şekilde pek çok yönden yararlı ve fonksiyonel olmalarına karşın derhal görülebilen somut bir sonucu üretme gayesinden hareket eden faydacı eylemeler özelliğini taşımamaktadırlar. Anlaşılacağı üzere amaçlı ve faydacı olmama, biçimsellik, tekrarlanabilirlik, kalıplaşmışlık şeklinde sıralanabilecek özelliği diğer sanat türlerinden farklı olarak müziğe ritüel bir karakter kazandırmakta (Supicic, 1982:24-25), aynı zamanda ritüeli de tasvir eden bu özellikleri ile müzik, ritüel bir yapıyı temsil etmektedir (Alcorta, Sosis, 2005:345). Nitekim Snoek müzikle de ilişkilendirilen ritüel eylemin ayırıcı niteliklerini şöyle sıralamıştır:

Kültürel olarak oluşmuş, geleneksel olarak onaylanmışlık; davranış, praksis, performans, bedensel eylem ve/ya sözlü eylem; katılımcılara sahip olmak; gündelik yaşamın sınırlarından ayrışmak, çerçeveli, liminal, yapısız; belirli bir yer ve zamanda meydana gelmek; kolektif, umumi; ...toplum ya da toplumsal grubu yaratmak ya da organize etmek; geçiş ve değişimi meydana getirmek; katılımcı için belirli bir amacı taşımak; tekrarlanabilir; standardize olmuş, ezberlenmiş; dinî, kutsal, transandantal; katı, kalıp yargısal, değişmez; dayanıklı, tekrarlı; katılımcı için anlamlı, sembolik; iletişimsel; araçsal olmayan; kurallı, metinli; biçimlenmiş, muhafazakâr; gelenekleşmiş; yapılanmış, kalıplaşmış, düzenli, ardışık, kural yönetimli; duyguların kanalı olmak (Snoek 2006:11).

Dolayısıyla ritüellere eşlik etmesinin ve bu bağlamda bir anlam ve önem kazanmasının ötesinde taşıdığı karakteristik özellikleri itibariyle müziğin bizatihi kendisi de bir ritüel niteliğini taşımaktadır. Bu doğrultuda olmak üzere müzik ve dinî pratikler arasındaki ilişki müzik ve ritüel/seremoni şeklinde ele alınabildiği gibi seremoni ya da ritüel olarak müzik şeklinde de ele alınabilmektedir. Ancak daha önce de belirtildiği üzere müziğin seremonik ya da ritüel boyutu ile ritüel ya da seremoni ile ilişkisini sosyokültürel bağlamı ve bu bağlamda açığa çıkan etkilerini dikkate almaksızın değerlendirmek mümkün değildir. Zira bir ritüel olarak değerlendirilip değerlendirilemeyeceği bir yana müzik ve ritüel birbiriyle ilişkili olduğu sürece bir anlam ve etkiden söz edilebilmektedir (Supicic, 1982:23-24).

Müzik ve ritüelin bir aradalığının en tipik sosyokültürel bağlamını din oluşturmakta, her ikisi de dindarlık çerçevesinde etkin rolleri oynamaktadır. Dinin kutsallarıyla sınırlandırılamayacak geniş bir alanın kutsallarından 
beslenmesine ve bu kutsalları beslemesine rağmen birey ve toplum arasında kurduğu köprülerle ritüeller, dinlerin ayrilmaz bileşeni olagelmişlerdir. Zira ritüeller ve dinî pratikler olmaksızın dinî inançlar duygusal ve toplumsal boyutlarından, güdüleyici güçlerinden tümüyle yoksundurlar. Ritüeller ise biçimsellik, kalıplaşmışlık, ve tekrarlanabilirlik gibi temel yapısal özelliklerini "ritmik güdüleyiciler" vasıtasıyla kuvvetlendirdiklerinden müzik ritüellerin ayrılmaz bir bileşenini oluşturmaktadır. Ritüeller müzik, ilahi, dans gibi ritmik güdüleyicilerin gücünden ritüele katılımı artırmak için de yararlanmaktadır. Müziğin duygusal bir coşkuyu yaratma, duyguların ifadesi için meşru bir ortam oluşturma özelliği ritüellere katılımı teşvik eden temel niteliklerindendir (Alcorta, Sosis, 2005:336-337, 343-344). Dinin sosyokültürel bir hüviyet kazanacak biçimde kendisini ifade ettiği (Bouchard, 1990:367) güçlü bir kanal olarak müziğin duygusal yaşamı diğer sanat türlerine göre daha yoğun bir biçimde etkileme özelliği ritüellerdeki uzun soluklu varoluşunun zeminini hazırlamaktadır (Andrews, 1916:331).

Güçlü bir duygu yaratıcısı ve dönüştürücüsü olarak müzik, dinî inanç ve uygulamaların duygusal bir tecrübe içinde öğrenilmesinin önünü açtığı gibi, eşlik ettiği ritüel bağlamında adanmışlık ve dindarlık hissinin artmasına (Woolston, 1902:75) ve dindarlıkta bir derinleşmenin yaşanmasına neden olmaktadır. Dolayısıyla müzik gibi ritmik eylemler yarattıkları duygusal etkiler ile ritüellere ve ritüellerde güdülenmek için duygusal bir koşullanmayı meydana getirmektedir. Daha açık bir ifadeyle müzik hem dinî tecrübeye katılımı hem de dinî tecrübenin kendisini yoğunlaştırıp kuvvetlendiren bir etkiyi yaratmakta (Hays, Minichiello, 2005:84, 95), dinin mutluluk ve üzüntü, umut ve korku gibi tecrübeleri ifade edecek sembol kaynaklarını oluşturma eğilimi de ritüeller bağlamında müziğin önemini artırmaktadır (Eurich, 2003:60). Müziği dinin toplumsal boyutu bağlamında ritüeller ekseninde önemli kılan bir diğer hususa Stokes işaret etmiştir. Buna göre dinin inanç ve değer sistemi ile sosyal gerçekliğin uyuşmadığı durumlarda ortaya çıkan teodise sorunun aşılmasında, bir kırılmaya mahal vermeden dinin değer sistemi ile sosyal gerçekliğin uzlaşmasında müzik etkin bir rol oynamaktadır. Stokes, bu durumu arabesk müzik örneğinde ele almış ve arabesk içindeki dinî referanslara özellikle de teodise kavramını karşılayacak referanslara dikkat çekmiştir. Arabesk müziğin teodise vurgusu yüksek karakteri, inanç sistemi ile sosyal tecrübelerin örtüşmediği durumlarda inanç sistemi ile sosyal gerçeklik arasında meydana gelen çatlağı doldurmaktadır (Stokes, 1992:225).

İnanç sistemi ile sosyal gerçeklik arasında meydana gelen bu türden k1rılmaların müzik vasıtasıyla doldurulmasının ardında müziğin dramatizas- 
yon gücünü aramak gerekmektedir. Zira, dramatizasyon sosyal çatışma ya da kırılmaların müzik gibi ritüel bir ortam içinde tiyatro sahnesini andıran bir temsille sunulmasını, böylece yıkıcı etkileri dondurulmak suretiyle kabullenilmesi ve meşruiyet kazanmasını sağlamaktadır. Dolayısıyla sanatsal bir temsil (gösteri) olarak müzik yarattı̆̆ 1 dramatik ritüel ortam ile inanç ve sosyal gerçeklik arasında meydana gelen kırılma ve krizi sanatsal bir sunum üzerinden meşrulaştırmakta ve toplumsal bir kabulle karşılanmasını sağlamaktadır. Turner, ritüellerin dramatizasyon vasıtasıyla sosyal çatışmaları meşrulaştırarak toplumsal bütünleşmenin devamlılığını sağlayan bu gücüne "sosyal drama" kavramıyla işaret etmektedir. Buna göre ritüellerin liminal aşamasında meydana gelen telafi edici mekanizmalar ya bütünleşmeyi yeniden sağlanmakta ya da tamiri olanaksız çatışmaları meşrulaştırmak suretiyle sosyal yeniden tanıma ve onayı oluşturmaktadır (Turner 1974: 37-41).

Ritüelleri çatışmaların ifade edildiği, bir onarım ve telafi mekanizması olarak gören Turner'in bu telafi ve onarımı ritüellerin gündelik yaşamın ötesine geçişi ifade eden liminal aşamayla özdeşleştirmesi müziğin gündelik yaşamın sınırlarının ötesine taşıyan gücünü akla getirmektedir. Öyle anlaşılıyor ki müzik, gündelik yaşamın sınırlarının ötesine taşıyan gücü vasıtasıyla sosyal gerçeklik ile değerler sistemi arasında oluşan boşluğun doldurulmasını, sosyal çatışmaların eritilmesini sağlamaktadır. Böylece müzik ve ritüel, mevcut fiili dünyanın ötesine taşıma ve bir dönüşümü sağlama eylemi üzerinden bir diğer ortak nitelikte daha buluşmakta, gündelik yaşamın ötesine taşıyan karakteri ile müzik ritüelle bir diğer ortak özelliği daha paylaşmaktadır. Müziğin etkileme gücünün temelinde de işte insanı mevcut dünyanın sınırlarının ötesine taşıyan, gündelik yaşam ile mevcut fiili durumdan sıyrılmayı sağlayan, estetik bir tecrübeyi oluşturan bu özelliği yatmaktadır. Müziği dinleyen, ritüelleri izleyen ya da katılan kişi mevcut gündelik yaşamın kısıtlama ve yükümlülüklerinin ötesine geçmekte, sınırsız zevklerin tecrübe edilebildiği farklı bir dünyaya adım atmaktadır (Supicic, 1982:25-26). Gündelik yaşamın ötesine böylesi bir geçiş ise sosyal yapının sınırlılıklarının ortadan kalktığı, belirli bir süreliğine de olsa farklılaşmamış bir ilişki ve toplum tipinin meydana geldiği bir durumu ifade etmektedir ki böylesi bir oluşum Turner'in bir diğer kavramı olan ve yine liminal aşamada meydana gelen komunitası çağrıştırmaktadır.

Turner'e göre liminalite kişinin sıradan gündelik ve seküler ilişkilerden ayrılmasını işaret eden ölüm ya da öldürmenin ritüel metaforlarıyla başlayan, sembolik yeniden doğum ya da yasa ve ahlaki kodlarla karakterize olan toplumla yeniden bütünleşme ile sonuçlanan geçiş ritlerinin orta aşamasını karşılamaktadır (Turner 1974:273, 52-53). Kutsal bir niteliğe sahip olan ya 
da kolaylıkla kutsallık kazanabilen bu liminal aşamada farklılaşmamış ve eşitlikçi toplum ve sosyal ilişki biçimlerini ifade eden komunitas meydana gelmektedir (Turner 1974:47, 237-238). Komunitas ve liminalite ise "kök metaforların", "kavramsal arketiplerin", "paradigmaların", "model for"un üretilmesinin koşullarını oluşturmaktadır (Turner 1974:50-51).

Turner'in bakış açısıyla konu ele alındığında gündelik yaşamın ötesine geçişi sağlayan nitelikleri ile ritüel ve müzik ya da ritüel müzik kutsal bir karakter taşıyan liminal aşamada nihayetinde sosyal yaşamla bütünleşmeyle sonuçlanacak farklılaşmamış eşitlikçi bir toplum ve ilişki biçimini yaratmaktadır. Gündelik yaşamın ötesine taşımak suretiyle kutsallığı ve bu kutsallık bağlamında yaratılan toplum ve toplumsal davranış biçimleri ile ritüel ve müzik sosyokültürel yaşamın devamlılığını sağlayacak inanç ve ideolojileri üretmektedir. Başka bir ifadeyle sosyokültürel yaşamın tek bütün ve uyumlu bir biçimde devamlılığı için gereken metaforu kutsallıkla ilişkilendirerek yaratmakta, ritüel içinde sosyokültürel yaşamın devamlılığı için metaforik bir model oluşturmaktadır. Söz konusu bu model toplumsal yaşamda kutsalın metafor merkezinde paylaşılmasını sağlamak suretiyle sosyal ve kültürel hayatın uyum içinde devamlılı̆̆ının zeminini hazırlamaktadır.

Öyle görünüyor ki müzik ve ritüel sadece kutsalın varlığına işaret etmekle sınırlı bir etki yaratmamakta aynı zamanda kutsalı ya da kutsalları da yaratmakta (Alcorta, Sosis, 2005:332), kültürel değerler ile sosyal normların kutsallıkla katışık bir algı içinde kabullenilmesini, sosyokültürel yaşamın devamlılı̆̆ını sağlamaktadır. Dolayısıyla inancın toplumsal ifadesi ve tecrübesi müziğin ritüel bağlamı çerçevesinde kurulmakta, bireysel ve toplumsal bağl1lık ve adanmışlık oluşturulmakta ve geliştirilmektedir (Hays, Minichiello, 2005:92-93). Nitekim Warner, ritüel ve müziğin birey ve toplum arasında bir köprü kurmak suretiyle sosyal yaşamın uyumlu bir biçimde devamlılığını sağlama niteliğine bir sivil dinin varlığından bahsedilen Amerika örneğinde işaret etmiştir. Warner'e göre birey ve toplum arasında bir köprü kuran ritüeller ile linguistik ve kültürel sınırlar arasında bir köprü kuran müziğin Amerika'daki göçmen topluluklarında bağlayıcı ve yaratıcı bir rolü bulunmaktadır. Ritüeller bağlamında müzik bireysel ve toplumsal tecrübeyi bir araya getirmekte, bir biz duygusunun meydana gelmesini sağlamaktadır (Warner, 1997:224, 226-229). Yine bu çerçevede olmak üzere müzik ritüeller bağlamında etnik grup dayanışması ve milli kimliğin güçlendirilmesi için de önemli bir araç olma özelliğini taşımakta, dinî atıflara müracaat ederek, kutsalı da katıştırarak milli duyguları güçlendirecek bir etkiyi beraberinde getirmektedir (Clark, 2006:477). Nitekim Meizel'in sivil din örneğinde işaret ettiği üzere müzik, dinî referansları kullanarak milli bir 
kimlik ve aidiyetin oluşmasını sağlarken sivil din ise kutsalla katışık bir milli kimliği oluşturmak üzere müziği etkilemektedir (Meizel, 2006: 498).

Anlaşılacağı üzere müzik kutsal ya da dinî bir bağlam çerçevesinde icra edilmese bile ritüel bir bağlam ekseninde kutsallık kazanmakta (Hills, Argyle, 1998: 91-93) aynı zamanda da bu ritüel bağlamı ile müzik kutsalın yaratılması ve paylaşılmasının zeminini hazırlamaktadır. Müzik ve ritüel kutsalı barındıran nitelikleri ile davranışı teşvik etmekte, grup dayanışması ve uyumunu sağlamakta, toplumsal duyguların zaman ve mekân sınırı olmaksızın canlı tutulmasına neden olmaktadırlar. Dolayısıyla müzik ritüeller bağlamında kutsallaşacak ve kutsalı yaratacak bir biçimde anlamlı ve önemli hale gelmektedir. Bu yönüyle ritüel başlı başına dönüştürücü bir güce sahiptir. Müziğin ritüel bağlamda anlamlı hale gelişi ritüellerin sosyal ve kültürel sonuçları da bu dönüştürücü gücüne işaret etmektedir (Alcorta, Sosis, 2005:336-337, 349).

\section{SONUÇ}

Ritüel ve müzik, kolektif bir coşkuyu üreten, sosyokültürel yaşamın temsili bir modelini sunan nitelikleri ile dinî hayatın sosyokültürel yaşamla bütünleşmesinde, dindarlığın toplumsal boyutunun temel karakterinin belirmesinde etkin roller oynamaktadır. Tekrarlanabilirlik, kalıplaşmışlık, ardışıklık gibi ritmik yapısal özellikleri ile sembolik anlamsal içerikleri bir yandan inancın öğrenilmesini temin ederken diğer yandan da inancın kolektif bir paylaşımın konusu haline gelmesini sağlamaktadırlar. Böylece bireysel bir tecrübenin konusu olan inanç, müziğin de eşlik ettiği ritüeller bağlamında toplumsal bir boyut kazanmakta, ritüeller vasıtasıyla birey ve toplum arasında güçlü bir köprü kurulmaktadır.

Söz konusu kolektif paylaşım bir yandan dinî ritüellere katılımı artırarak dindarlıkta bir derinleşmeyi beraberinde getirirken diğer yandan da sosyokültürel değerler ile bu değerlere uygun davranış biçimlerinin edinilmesinin önünü açmaktadır. Ayrıca, ritüel ve müzik sosyalizasyonu sağlamak suretiyle doğrudan sosyal bütünleşmeyi yaratabildiği gibi çatışmaları dramatize ederek de sosyal bütünleşmenin devamlılı̆̆ını temin etmektedir.

\section{KAYNAKÇA}

Alcorta, Candace S. ve Richard Sosis (2005), "Ritual, Emotion, and Sacred Symbols The Evolution of Religion as an Adaptive Complex", Human Nature, , 16/4, ss. 323-359.

Andrews, George W. (1916), "Music as an Expression of Religious Feeling", The Musical Quarterly, 2/3 ss. 331-338.

Begbie, Jeremy S. (2000), Theology, Music \& Time, Cambridge University Press, Port Chester. 
Blau, Judith R. (1988), "Music as Social Circumstance",Social Forces, 66/4, pp. 883-902. Bouchard, Larry D. (1990), "The Arts and the Knowledge of Religion", The Journal of Religion, 70/3, ss. 353-367.

Cerulo, Karen A.(1984), "Social Disruption and Its Effects on Music: An Empirical Analysis", Social Forces, 62/4, ss. 885-904.

Clark, Lynn S. (2006), "Introduction to a Forum on Religion, Popular Music, and Globalization", Journal for the Scientific Study of Religion 45/4, ss.475-479.

Durkheim, Emile (1947), The Elementary Forms of the Religious Life: A Study in Religious Sociology, Translated from the French by Joseph W. Swain, Free Press, Illinois.

Elias, Norbert (2000), Mozart Bir Dahinin Sosyolojisi Üzerine, Çev. Yeşim Tükel, Kabalc1, İstanbul.

Eurich, Johannes (2003), "Sociological Aspects and Ritual Similarities in the Relationship between Pop Music and Religion", International Review of the Aesthetics and Sociology of Music, 34/1 ss. 57-70.

Feld, Steven (1984a), "Communication, Music, and Speech about Music", Yearbook for Traditional Music, 16,ss. 1-18.

Feld, Steven (1984b), "Sound Structure as Social Structure", Ethnomusicology, 28/3 ss.383-409.

Feld, Steven ve Aaron A. Fox (1994), "Music and Language", Annu. Rev. Anthropol.. 23, ss.25-53.

Geertz, Clifford (2004), "Religion as a Cultural Sysyem", In Anthropological Approaches to the Study of Religion, Michael Banton (ed.), Routledge, London. Goffman, Erving (2006), Interaction Ritual Essays in Face-to-Face Behavior, Aldine Transaction, London.

Hays, Terrence ve Victor Minichiello (2005), “Older People's Experience of Spirituality Through Music", Journal of Religion, Spirituality \& Aging, 18/1, ss.83-96.

Hills, Peter ve Michael Argyle (1998), "Musical and Religious Experiences and Their Relationship to Happiness", Personality and Individual Differences, 25, ss.91-102.

İbn Haldun (1991), Mukaddime II, Çev. Zakir Kadiri Ugan, Milli Eğitim Bakanlığı Yayınları, İstanbul.

Kaemmer, John E. (1980), "Between the Event and the Tradition: A New Look at Music in Sociocultural Systems", Ethnomusicology, 24/1, ss. 61-74.

Lengel, Laura (2004), "Performing in/outside Islam: Music and Gendered Cultural Politics in the Middle East and North Africa", Text and Performance Quarterly, 24/34, ss. 212-232.

Meizel Katherine (2006), "A Singing Citizenry: Popular Music and Civil Religion in America", Journal for the Scientific Study of Religion 45/4, ss.497-503.

Platvoet, Jan G. (2006), "Ritual: Religious and Secular", In Theorizing Rituals, Issues, Topics, Approaches, Concepts, Jens Kreinath, Jan Snoek, Michael Stausberg (eds.), Brill, Leiden.

Regelski, Thomas A. (2006), "Music Appreciation' as Praxis", Music Education Research, 8/2, ss. 281-310.

Segal, Robert A. (1983), "Victor Turner's Theory of Ritual”, Zygon, 18/3, ss.327-335.

Snoek, Jan A.M. (2006), "Defining 'Rituals"', In Theorizing Rituals, Issues, Topics, Approaches, Concepts, Jens Kreinath, Jan Snoek, Michael Stausberg (eds.), Brill, Leiden.

Stack, Steven ve Jim Gundlach (1992), "The Effect of Country Music on Suicide”, Social Forces, $71 / 1$ ss. 211-218. 
Stausberg, Michael (2006), "Ritual': A Lexicographic Survey of Some Related Terms From an Emic Perspective", In Theorizing Rituals, Issues, Topics, Approaches, Concepts, Jens Kreinath, Jan Snoek, Michael Stausberg (eds.), Brill, Leiden.

Stokes, Martin (1992), "Islam, the Turkish State and Arabesk", Popular Music, 11/2, A Changing Europe, ss. 213-227.

Supičić,Ivo (1982), "Music and Ceremony. Another Aspect", International Review of the Aesthetics and Sociology of Music, 13/1, ss. 21-38.

Tracey, Hugh (1954), "The Social Role of African Music", African Affairs, 53/212, ss. 234-241.

Turley, Alan C. (2001), "Max Weber and the Sociology of Music", Sociological Forum, 16/4, ss.633-653.

Turner, Victor (1974), Dramas, Fields, and Metaphors Symbolic Action in Human Society, Cornell University Press, New York.

Warner, R. Stephen (1997), "Religion, Boundaries, and Bridges", Sociology of Religion, 58/3 ss. 217-238.

Woolston, H. B. (1902), "Religious Emotion", The American Journal of Psychology, 13/1, ss. $62-79$. 